\title{
Occurrence of Conotrachelus psidii (Marshall, 1922) in Psidium cattleianum (Sabine)
}

\author{
Lucas Battisti ${ }^{1}$ (D), Michele Potrich ${ }^{2}$ (D), Américo Wagner Júnior ${ }^{3}$ (D), \\ Everton Ricardi Lozano ${ }^{2}$ (1D
}

${ }^{1}$ Programa de Pós-graduação em Agroecossistema - PPGSIS, Universidade Tecnológica Federal do Paraná - UTFPR, Dois Vizinhos/PR, Brasil

${ }^{2}$ Laboratório de Controle Biológico, Coordenação de Ciências Biológicas, Universidade Tecnológica Federal do Paraná UTFPR, Dois Vizinhos/PR, Brasil

${ }^{3}$ Coordenação de Agronomia, Universidade Tecnológica Federal do Paraná - UTFPR, Dois Vizinhos/PR, Brasil

\begin{abstract}
The guava weevil, Conotrachelus psidii (Marshall, 1922) (Coleoptera: Curculionidae), has been reported to be harmful to guava fruit, causing deterioration. However, the occurrence of this insect and resulting damage in araçazeiro Psidium cattleianum (Sabine) fruit has not yet been described. For this reason, the objective of this study was to report the occurrence of $C$. psidii in araçá (P. cattleianum). In May 2015, the occurrence of C. psidii in araça trees of the P. cattleianum species was investigated. Recordings were performed in the experimental area of UNEPE Viveiro de Plantas Hortícolas (geographical coordinates $25^{\circ} 41^{\prime} 37^{\prime \prime} \mathrm{S}$ and $53^{\circ} 06^{\prime} 07^{\prime \prime} \mathrm{W}$, average altitude of $502 \mathrm{~m}$ ) at the Federal University of Technology (UTFPR-DV), Dois Vizinhos - PR.
\end{abstract}

Key words: araçá; insect pest; guava weevil. 
The guava weevil, Conotrachelus psidii, is an insect of the Coleoptera order and Curculionidae family (Silva, 2009). It is characterized as a small beetle that measures approximately $6 \mathrm{~mm}$ in length and has dark brown coloring, with elytra that have longitudinal grooves covered by short and fine arrows and are colored white or yellow (Gallo et al., 2002; Sá \& Silva, 2011). Four to five days after the eggs are laid, white apodal larvae with dark-colored head hatch, and after four days, leave and become pupa in the soil. This period takes approximately 16 days (Gallo et al., 2002), while adults can survive up to seven months (Silva, 2009).

Conotrachelus psidii has a negative impact on the production and commercialization of fruit in several countries, including Brazil, due to early ripening and rotting, giving them an unpleasant appearance (Valente $\&$ Benassi, 2014). In addition to larvae damaging the fruit, adults may damage other plant organs, such as flower buds, petioles and stems (Silva-Filho et al., 2007). This insect, C. psidii, is one of the main pests of guava, Psidium guajava (L.), in Brazil. The larvae of this insect damage guava fruit by destroying the pulp and seeds, leaving the inner part of the fruit with blackened appearance and, therefore, causing problems for producers (Gallo et al., 2002; Silva, 2009). Guava fruits attacked by $C$. psidii present depressions in the epicarp and black spots at the posture site.

Brazil has potential to produce native fruit trees, such as Psidium cattleianum (Sabine), popularly known as red or yellow araçá. It belongs to the family Myrtaceae and the genus Psidium, the same as P. guajava. P. cattleianum is a plant which is native to Brazil, present in the Atlantic Forest (mixed and dense ombrophilous forest) and can occur from Bahia to Rio Grande do Sul (Silva et al., 2011), being prominent in the South of Brazil (Tomaz et al., 2011). The araçá is cultivated in domestic orchards in the South of Brazil, is an arboreal species, has a height of 1 to 9 meters and brown trunk. It has leaves of 5 to $9 \mathrm{~cm}$ in length and white axillary flowers, which appear between September and December (Muller et al., 2012). The fruit can be yellow or red, which suggests that there are two morphotypes (varieties) of the species, and the flavor is similar to the guava, but less acidic (Rocha et al., 2008).

Psidium cattleianum has significant economic importance, being used to generate heavy and compact wood which is suitable for use in civil construction and the manufacture of tool cables, for example. This species is also recommended for areas of environmental recovery. The fruit is used by humans in various ways, such as the preparation of jellies, juices and liqueurs, due to their nutritional characteristics (Sousa \& Sobral, 2007). However, the productivity of $P$. cattleianum can be compromised by several factors, one of them being the attack by insect pests.

In the experimental area of UNEPE Viveiro de Plantas Hortícolas (geographic coordinates 2541'37"S and $53^{\circ} 06^{\prime} 07^{\prime \prime} \mathrm{W}$, average elevation of $502 \mathrm{~m}$ ) at the Federal University of Technology, Campus Dois Vizinhos (UTFPR-DV), fruit damaged by C. psidii attack was studied. The area of the araçazeiro orchard comprised 300 plants of the cultivar Ya-CY, which has yellow pulp. The plants originated from seeds planted in 2010 in an area of $1.0 \times 2.5 \mathrm{~m}$.

The infected fruits were transported to the Laboratory of Biological Control I at UTFPR-DV where the material was analyzed. There were depressions in the fruit bark, along with black scores left by oviposition (Figure 1A), as described by Gallo et al. (2002) and Silva (2009) in P. guajava infected by C. psidii.

Analysis of the fruits confirmed the presence of larvae. These were identified according to Gallo et al. (2002) as the larvae of the guava weevil, C. pisidii, with a scarabaeiform shape, apex, white color, dark head and $8 \mathrm{~mm}$ in length (Figure $1 \mathrm{~B}$ and $\mathrm{C}$ ). The larvae feed on the pericarp, and also on the seeds of the fruit; the blackened color of the pulp, which was observed here, is characteristic of infestation by the guava weevil.

Infestation with C. psidii has already been reported in the guava serrana Acca sellowiana (Bohneberger, 2009). However, there are no reports in the literature of its occurrence in Psidium cattleianum, this is the first record in this species.

Biological control through the release of parasitoids and predators has been studied, as well as the cultural control, accomplished by manual harvesting and destruction of fallen fruits (Gallo et al., 2002; Duarte et al., 2013).

Due to the lack of chemicals registered to control the guava weevil (Brasil, 2016), understanding the biology and ecology of this insect is important for the development of alternative methods of control. Biological control, involving the release of parasitoids and predators, has been studied, as well as cultural control, such as manual scavenging and destruction of fallen fruit (Gallo et al., 2002; Duarte et al., 2013). 

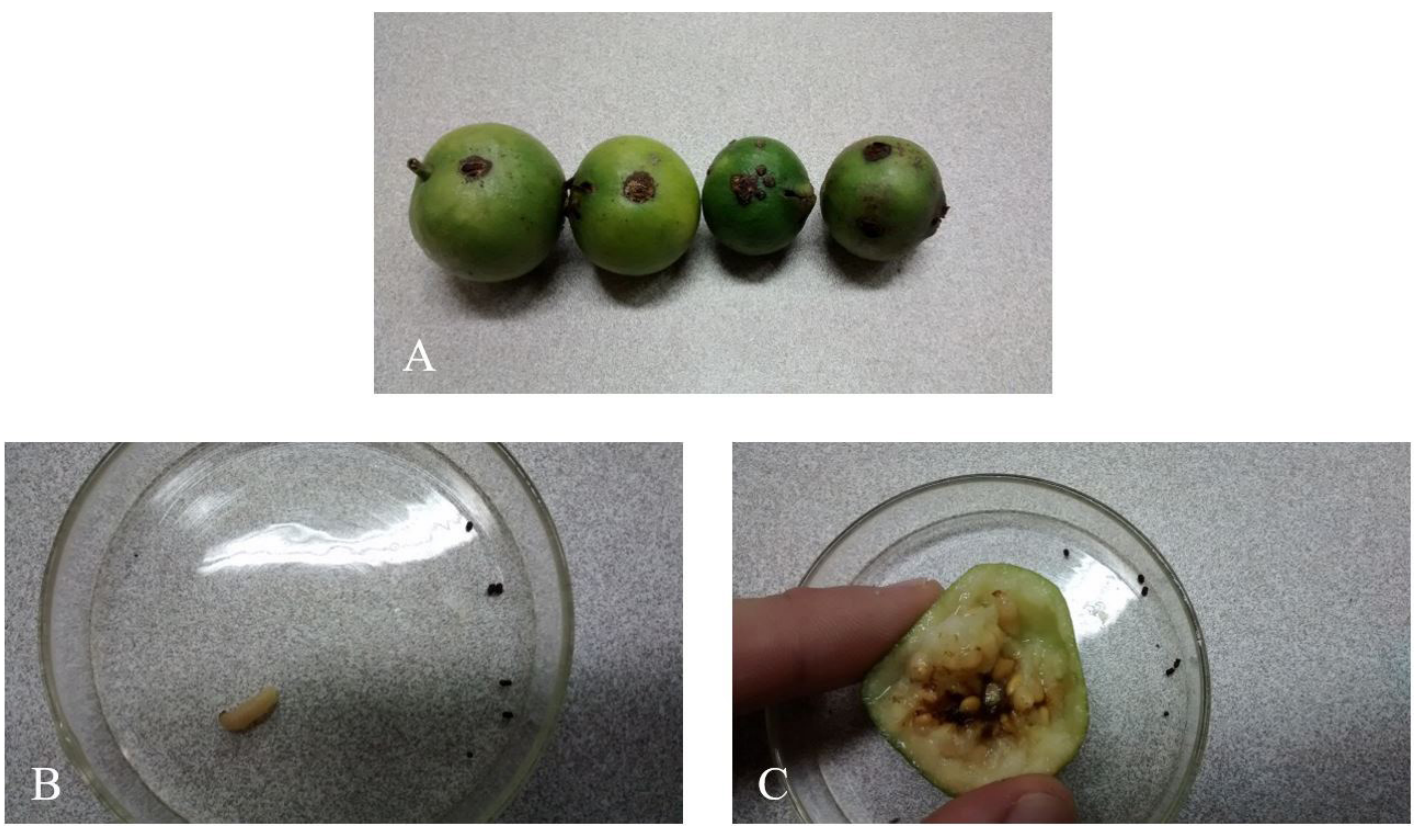

Figure 1. A) Psidium cattleianum fruit with depressions and black spots on the epicarp; B) Larvae of Conotrachelus psidii; C) Open Psidium cattleianum fruit showing infestation with the guava weevil (Conotrachelus psidii).

Therefore, studies that investigate the occurrence of C. psidii in P. cattleianum in different regions and biomes are extremely important for understanding the dispersion capacity of this insect, the potential damage it can cause, and basic information that can contribute to improving the management of this crop, preventing attack by $C$. psidii or providing subsidies for further research. However, it is necessary to carry out new studies on the herbivore-plant relationship involving C. psidii and P. cattleianum.

\section{SUBMISSION STATUS}

Received: 8 sep., 2016

Accepted: 26 feb., 2018

\section{CORRESPONDENCE TO}

\section{Michele Potrich}

Laboratório de Controle Biológico, Coordenação de Ciências Biológicas - COBIO, Universidade Tecnológica Federal do Paraná, Câmpus Dois Vizinhos - UTFPR-DV, Estrada para Boa Esperanca, CEP 85660-000, Dois Vizinhos, PR, Brasil

e-mail: profmichele@gmail.com

\section{FINANCIAL SUPPORT}

CAPES (Coordination for the Improvement of Higher Education Personnel) for the scholarship granted to the first author.

\section{REFERÊNCIAS}

Brasil. Ministério da Agricultura, Pecuária e Abastecimento. Sistemas de Agrotóxicos Fitossanitários - AGROFIT [online]. Brasília: MAPA; 2016 [cited 2016 Apr 5]. Available from: http://agrofit.agricultura.gov.br/agrofit_cons/ principal_agrofit_cons

Bohneberger AL. Ocorrência do gorgulho Conotrachelus psidii (Coleoptera: Curculionidae) e manejo das principais doenças e pragas na goiabeira serrana Acca sellowiana com ênfase na homeopatia [dissertação]. Lages: Universidade do Estado de Santa Catarina; 2009.

Duarte RT, Galli JC, Pazini WC. Levantamento populacional de predadores (Arthropoda) em cultivo orgânico de goiaba (Psidium guajava L.). Revista Agroambiente 2013; 7(3): 352-358.

Gallo D, Nakano O, Silveira-Neto S, Carvalho RPL, Baptista GC, Filho EP et al. Entomologia Agrícola. São Paulo. Biblioteca de Ciências Agrárias Luiz de Queiroz; 2002.

Muller NTG, Fasolo D, Bertê B, Ely CV, Holz DT. Análise fitoquímica das folhas de myrtaceae: Psidium cattleianum 
Sabine E Campomanesia guazumaefolia (CAMB.) Berg. Revista Eletrônica de Extensão da URI 2012; 8(14): 65-71.

Rocha LD, Preussler KH, Pegorini F, Farias V, Maranho L. Estudo anatômico comparativo da casca do caule do araçáamarelo e araçá-vermelho, Psidium cattleianum Sabine, Myrtaceae. Acta Botanica Brasílica 2008; 22(4): 1114-1122. http://dx.doi.org/10.1590/S0102-33062008000400022.

Sá VA, Silva LB. infestação de Conotrachelus psidii Marshall (coleoptera: curculionidae) em frutos de goiaba, Psidium guajava L. (myrtaceae), em Mato Grosso do Sul, Brasil. Revista de Biologia e Farmácia 2011; 6: 123-128.

Silva-Filho G, Bailez OE, Viana-Bailez A. Dimorfismo sexual do gorgulho-da-goiaba Conotrachelus psidii Marshall (Coleoptera: Curculionidae). Neotropical Entomology 2007; 36(4): 520-524. http://dx.doi.org/10.1590/S1519566X2007000400006. PMid:17934614.

Silva AC. Potencial de nematóides entomopatogênicos para o controle da mosca-do-mediterrâneo Ceratitis capitata (wiedemann) (diptera: tephritidae) e do gorgulhoda-goiaba Conotrachelus psidii (marshal) (coleoptera: curculionidae) [dissertação]. Faculdade de Ciências
Agronômicas, Universidade Estadual Paulista "Júlio de Mesquita Filho; 2009.

Silva A, Perez SCJGA, Paula RC. Qualidade fisiológica de sementes de Psidium cattleianum Sabine acondicionadas e armazenadas em diferentes condições. Revista Brasileira de Sementes 2011; 33(2): 197-206. http://dx.doi.org/10.1590/ S0101-31222011000200001.

Sousa LP, Sobral MEG. Morfotipos do araçazeiro (Psidium cattleianum Sabine) no estado do Paraná. In: Pedrosa-Macedo JH, Dalmolin A, Smith, CW, editores. $\mathrm{O}$ araçazeiro: Ecologia e controle biológico. Curitiba: FUPEF do Paraná; 2007.

Tomaz ZFP, Galarça SP, Lima CSM, Betemps DL, Gonçalves MA, Rufato AR. Tratamentos pré-germinativos em sementes de araçazeiro (Psidium cattleyanum Sabine 1.). Revista Brasileira Agrociência 2011; 17: 60-65.

Valente FI, Benassi VLRM. Aspectos biológicos e técnica de criação do gorgulho-da-goiaba, Conotrachelus psidii marshall (coleoptera: curculionidae). Revista Brasileira de Fruticultura 2014; 36(2): 339-345. http://dx.doi. org/10.1590/0100-2945-213/13. 